The Journal of Society and Media, October 2020, Vol. 4(2) 348-366

https://journal.unesa.ac.id/index.php/jsm/index

E-ISSN 2580-1341 and P-ISSN 2721-0383

Accredited KEMENRISTEK/BRIN No.148/M/KPT/2020

DOI: 10.26740/jsm.v4n2.p348-366

\title{
The Strategy of Poor Students Dealing with The Home-Learning System
}

\author{
Nanang Martono ${ }^{*}$, Nabilla Khansa Naura ${ }^{2}$, Rahma Isnania $^{3}$, Lisnawati ${ }^{4}$, \\ Rakhma Nugraheni ${ }^{5}$ \\ 1,2,3,4,5 Program Studi Sosiologi, Fakultas Ilmu Sosial dan Ilmu Politik, Universitas \\ Jenderal Soedirman, Purwokerto, Jawa Tengah, Indonesia \\ Email: nanang.martono@unsoed.ac.id \\ Email: nabilla.naura@mhs.unsoed.ac.id \\ Email: rahma.isnania@mhs.unsoed.ac.id \\ Email: lisnawati036@mhs.unsoed.ac.id \\ Email: rakhma.nugraheni@mhs.unsoed.ac.id
}

\begin{abstract}
This paper describes the strategy of poor students dealing with the home-learning system in the time of COVID-19. The home-learning system, however, theoretically generates the digital divide for the majority of poor students because they have less capital and resources. In order to be involved in the system, they have to afford themselves in getting the digital devices, such as smartphones and laptop. It uses the qualitative method undertaken in four regencies: Banyumas, Purbalingga, Banjarnegara, and Tegal. The poor students who undergo the home-learning system in those regencies are enlisted to be purposive samples. The profile is selectively included because of their lack of means in dealing with the system. For this study, we analyze the data collected from in-depth interviews, observation, documentation, followed by constant comparative analysis. The result indicates that most poor students only have the worksheets (LKS) and books as their primary learning resources. The poor students cannot optimally undergo the system due to the financial constraints which lead to the shortage of use of technology. Also, the intensity of parental participation during school hours is low due to their educational background and working hours. The condition is also worsened by the absenteeism of the teacher.
\end{abstract}

Keywords: poor student, home-learning system, social reproduction.

Paper type: Research paper

*Corresponding author: nanang.martono@unsoed.ac.id

Submitted: 2020-08-03; Accepted: 2020-10-30; Published: 2020-10-30

Cite this document: Martono, N., et. al. (2020). The Strategy Of Poor Students Dealing With The Home-Learning System. The Journal of Society and Media, 4(2), 348-366.

DOI: $10.26740 / j s m . v 4 n 2 . p 348-366$ 


\section{INTRODUCTION}

The coronavirus outbreak has affected the lives of society with many social impacts ever since the beginning of 2020. The outbreak has recorded many victims so that the immediate agile solutions are supposedly proposed. Nevertheless, the government responded to the situation by putting the motion into regulations. They are functioned to decrease the number of victims due to the pandemic. The order undertaken by the government is to precaution society to avoid crowded places and implement a healthy lifestyle anytime and anywhere.

The education, however, is inclusively targeted by the regulation because school is one of the public places -face-to-face interactions and mass gatherings. They are possible for coronavirus transmission. Referring to the problem, the COVID-19 has resulted in schools closed. The students and teachers are highly prohibited to hold on-site activities at school. The government also emphasizes the home-learning system that applies to all levels, ranging from kindergarten to higher education. It has started from the end of March 2020 to an unspecified amount of time.

Not only does the system remain practiced in Indonesia, but also applies in almost all of the countries across the globe. They keep the schools shut and are shifting to home-learning approaches. The closure aims to slow the spread of the coronavirus and flatten the curve. In other words, the rise of the online learning system is happening.

The system, however, is not confusing if they are rounded up with supporting online resources, such as smartphones, laptops, or even computers. The learning system is done remotely by utilizing information technology (Martono, 2020). Arkoful \& Arbaidoo (2014) also argue that transferrable material and assignment in an online format utterly utilize the use of technology itself. Without the support of online resources, the system will be easily disrupted and lead to inefficiency and ineffectiveness.

Prior research by Arsendy, et. al. (2020) indicates that the shortage of remote resources for the system is confusing whereas some students have not been prepared enough through stimulations and practices beforehand. This may arise inequalities in accessing the home-learning system. A recent study by Saavedra (2020) also concluded that the approach is adopted all over the world. Otherwise, 
the practice of the home-learning system hit poor students much harder than the rich ones. The condition of poor students is exposed to exploitation or symbolic violence in education (Martono, 2020; Slameto, 2020). A more comprehensive explanation can be found in research conducted by Arsendy (2020), it reveals that there is an education inequality between the upper-class and the lower-class due to the shift to online learning. The research has examined that there were only $28 \%$ of parents stating that their children learned by digital devices. Other than that, the World Bank (Saavedra, 2020) estimated that nearly 1,6 billion children and young adolescences are out of school in 161 countries that most of them come from lowincome families.

An earlier contribution to the literature implied that the indication that the home-learning system exploited most of the students in Indonesia. Implicitly, the system asserts the bias of social class. First, the system is more likely to be fortunate for the students who have the means to the supporting resources (Acar, 2011). To optimize the home-learning system, a set of capital is required for them. A grand contribution by the thesis of Bordieu brought the information that there were four essential forms of capital needed by students: economic, social, cultural, and symbolic capital. On the contrary, if those capitals are not invested in students, they may be threatened by the occurrence of failing education achievement or facing the dropouts (Saavedra, 2020).

Seminal contributions have also been made to indicate that there is a linkage between the optimization of the home-learning system and the availability of online resources (Dhull \& Sakshi, 2017; Nguyen, 2015). Therefore, it is more guaranteed to the students living in urban areas whose resources are more accessible. They are spotty to be provided by various resources from digital technology. Meanwhile, the system creates a gigantic crisis for students in rural areas because of the unequal mechanism.

The study addresses several questions on analyzing the strategy undertaken by the poor students in dealing with the home-learning system during the pandemic. The question that then naturally arises is what kind of problems may occur during the home-learning system due to the shortage of forms of capital. A further systematic and theoretical analysis is required to describe the challenges faced by the poor students and their strategies to follow the system during the COVID-19. 
The poverty, however, is not a novel issue in the sociological approach. This research is more likely to refer to the social life of poor students had not been raised by their parents. They put their expectations to the relatives as well as they hope to get support during the process. In other words, this research attempts to define the strategy of poor students who face the digital divide and the social life for those who do not live with family members who are unable to help with learning.

\section{METHOD}

This research uses a qualitative method undertaken at four regencies in Central Java, namely Banyumas, Purbalingga, Banjarnegara, and Tegal. The poor students who undergo the home-learning system in those regencies are enlisted to be purposive samples. The profile is selectively included because of their lack of means in dealing with the system so they have to face the challenges for several months. The regions where they are located are branched into two areas, which are rural and urban areas. For this study, we analyze the data collected from indepth interviews, observation, documentation, followed by constant comparative analysis. The author initially collected the data through in-home interviews, followed by validating the answers from their families or relatives at home. The data were obtained separately at the same time, exploring their socioeconomic background, the everyday life during the pandemic, the roadblocks of homelearning system, and the strategies to overcome the problems. In general, this research projected the residential area and the educational resources.

\section{RESULTS AND DISCUSSION}

\section{a. The social facets of informants}

The home-learning system is an inauspicious circumstance for low-income students. It is substantively a form of learning activities that commands the students to run the schooling system at home during the pandemic. In other words, the students are forced to follow the order. As a consequence, they have to encounter some difficulties or even fail the system itself. Compared to those whose means are more accessible, they are not accustomed to using learning systems that are blended and entirely online. Students can fail in following the 
system during the pandemic. Here is the description of the social facets of informants collected in this study:

ADR. ADR is the only son who is also a first-grader of an elementary school in Purbalingga Regency. His father only graduated from elementary school and now works as a laborer. Otherwise, her mother was from junior high school and now becomes a housewife. He starts the day at 5 am and prepares himself for school which is located nearly 200 meters from his house. Back to the normal situation, he used to study at school until $10 \mathrm{am}$. Right after going back home, he spent his time playing with his friends. ADR and his family live in a wovenbamboo and floored house. The house cannot be called feasible because it is about to collapse. On the other side, he is a very sociable person and has various playmates. Not only does he play with his school friends, but also with his learning groups at Alqur'an Learning Centre.

ANG. ANG is a sixth-grader of an elementary school in Purbalingga Regency. Both of his parents only graduated from elementary school. His father is jobless, while her mother is working for an eyelashes factory in Purbalingga. His father always takes care of him at home. ANG, his parents, and her three siblings live in a plaster-floored small house whose living room is solely covered by thin carpet. As labor, her mother only earns money as much as a regional minimum wage. The income then is only able to meet their basic needs. On the other side, ANG has only fewer resources to accommodate his study. In comparison to ADR, he is a shy and reserved person.

DAF. DAF is a third-grader of elementary school at the southern part of Tegal Regency. Both of his parents have divorced ever since he entered the school. He lives with his grandmother in a doorless small clay-floored house. $\mathrm{He}$ used to live with his mother in Tangerang before moving to his grandmother's house three years ago. It is possibly clear that he does not speak Javanese fluently.

Talking about DAF's mother, she only graduated from elementary school and now works as a housemaid out of town. The income is as same as ADR's family where it solely meets their basic needs. Therefore, his mother always has to work hard so DAF can complete his study. On the contrary, his grandmother is listed for being the recipient of Program Keluarga Harapan, the conditional cash transfer program in Indonesia to reduce the burden of household expenditure. 
Daily, she works as a farmer from morning to earlier evening. The condition gets him lonely and chooses to spend his time with his friends.

FEB. FEB is a third-grader of an elementary school in Tegal Regency. He lives in a rent house with his parents. His father graduated from junior high school and now works as a freelancer. Sometimes, he works as a fishmonger at the market. Meanwhile, her mother only graduated from elementary school and now is a full-time housewife. Along with his parents, FEB lives in a disadvantaged condition. To reduce the burden of his mother, he always helps her in doing the household chores. Besides, he is not also the smartest kid at school, but he is enthusiastic to study hard amid his poverty line.

BIP. BIP is an elementary school student who lives in Banjarnegara. He is now studying in fifth grade. Both of his parents graduated from senior high school. His father sells coconut for living while his mother works as a housemaid. In the earlier evening, the mother helps her husband selling. Like other informants, the income of his family merely fulfills their basic needs. He also lives with his parents and his siblings in a decent house. His parents, however, are not the landlords. The house is rent by her mother's boss. Back to the normal situation, he used to start the day at $5 \mathrm{am}$. He went to school with his friends by bike, yet was accompanied by his father by motorcycle sometimes. After school was over, he practiced football with his playmates.

RRW. RRW is a third-grader of an elementary school in Banjarnegara. She has a good achievement at school where she is always in the top five in her class. Her father used to work as a school guard. However, he already passed away since RRW was little. Her mother graduated from senior high school and now has a small grocery story for living. For their basic needs, RRW and her mother also live with his father's pension fund. They also live in a small house with their relatives from RRW's mother. While in a normal situation, RRW used to start the day at $5.30 \mathrm{am}$. The school is nearly 600 meters from her house. She went to school with her cousins by motorcycle. Otherwise, she had to walk on her feet with his friends for going back home.

HNF is a fourth-grader of an elementary school in Purwokerto. He has a big sister who is also a student at vocational high school. Both of his parents graduated from senior high school. His father works as a shopkeeper, while his 
mother is a housewife. HNF and his sister usually go to school with their father by motorcycle. It aims to reduce transportation costs. Even though he was born in low-income families, he is a smart student at his school. Since he entered the school, he has always ranked in the top ten. The achievement makes his surroundings respect and proud of him. Not only does he get respect, but also is asked often for help from his classmates. Other than that, he sufficiently has learning resources because the school provides the students to borrow books as those are needed. HNF often goes to the library to borrow books to help him finish the assignments.

JEF is a student majoring at accountancy at vocational high school in Purwokerto. She is the first of three children. Her father graduated from senior high school and now works as a freelancer, while her mother is a full-time housewife. Talking about her younger sister, she was born with a psychological disability. She has suffered poor concentration ever since she was two years old. This might build her decision to go to vocational school so she can immediately be employed and help her family's living.

Despite her rough financial circumstance, JEF always gets high achievement at her school. She is always in the first position and becomes the icon among others. Not only does she focus on her academics, but also actively contributes to extracurricular programs. She takes part in the English club and Red Cross. She is fond of having new friends by participating in the clubs. In the dense time she has, JEF always makes her time to review the materials from $7 \mathrm{pm}$ to 8 pm. It becomes her routine because she realizes that the materials are not easily understandable. Therefore, she often reads them over every night.

\section{b. Home-Learning System in the Time of Covid-19}

The duty of learning from home has forced every student to adjust the shift to online learning. They have to follow the system where the teacher is physically absent in front of them. However, the interaction is formed by logging in the online classroom. Unfortunately, the poor students have dropped out of touch with schools completely - unavailable by phone, email, or any other form of communication - as their families struggle with the broader economic effects of the COVID-19. Most of them cannot fully comprehend the materials given in the online platform. 
The teacher's presence is highly on demand stated by all informants in this study. It is due to a lack of supporting roles in the studying process. Other than that, the materials are often complicated. To those whose means are well provided, it is not an obvious problem. They can maximize the use of digital devices to fill out the absenteeism. Those students who have facilities to attend online classes face barriers in terms of unavailability of physical space, which is equally applicable to the teachers who are supposed to conduct online classes from their homes. On the contrary, the poor students have to think it over and are disproportionately more hurt than their rich counterparts.

One of the informants, which is ADR, stated that he only has his books and worksheets as a means of studying. He considers himself lucky because his father can share digital devices to keep up with the online classroom. He also relies on the television channel of Televisi Republik Indonesia (TVRI) to expand his knowledge every morning. He has to go to his neighbor's house because there is no television at his house. ADR, however, loves to study with his friends if there is a group task. His father always helps him study at home. Otherwise, his mother never does that because she cannot comprehend the materials. To submit the assignments, he puts his paper and entrusts it to the grocery store nearby. The teacher then takes it over after completely submitted.

Contrary to the answers of ADR, ANG has a slight difference in schooling. ANG is talented at sports. He ever won a football match in a sub-district level. While conducting the home-learning system, ANG studies from his books as the primary sources. He also has the worksheets (Lembar Kerja Siswa) and the "Detik-Detik" book to practice due to a lack of online learning resources. As a consequence, he encounters challenges where all of the information are frequently delayed. He needs to wait from his friends to inform him of any assignments.

Instead, ANG likes to study all by himself at home. He claims that he is not likely to ask his friends because he is too shy. If he feels the obstacles get stronger, he will ask his close friends. According to the answer, mathematics and Javanese are the hardest subjects at school. Another problem he may encounter is to submit the assignment. He said that he never submitted his assignment because he could not capture and send it online. When he was questioned about his teacher's response, he was likely to answer that he did not know it at all. 
DAF, the student who lives with his grandmothers, also feels disadvantaged because of this unprecedented change. During the home-learning system, his study is fixated on the books he has. No one can help him to understand the materials because his grandmother is too busy to work. In other words, his studying process is uncontrolled. His grandmother also does not have any digital devices. Therefore, the studying process is thwarted by uneven access. This worsens the situation to log into the online classroom.

When DAF does not understand the materials, he needs to ask his friends and neighbors because his grandmother cannot offer any help. His complementary sources are also from the television. Nevertheless, it is not significantly efficient to increase understanding because it is prompt and not repeated.

Another problem is also experienced by FEB. However, he is more fortunate because his mother always accompanies and helps him study at home. $\mathrm{He}$ is more fond of studying at home rather than with his friends. If his mother does not comprehend the materials, he will ask his neighbor next to his house to help him.

During the home-learning system, he claims that he cannot fully keep up with the online classroom. He does not have digital devices, while her mother solely has an old phone without a camera. The problem is magnified by less-thanadequate learning sources. He often asks his neighbors for help to submit his assignments.

On the other side, BIP lives in a more proper condition than any other informants. Despite his low-income family, his parents can still afford him to have a secondhand smartphone. It no longer remains an obstacle for him to participate in online learning and submit his assignment. During the COVID-19, he can still access any information regarding the subject. Other than that, he does not have complete means of studying. He only uses his worksheets and books borrowed from the school. Another problem he encounters is no supporting roles in the studying process. It is because both of his parents are busy working. When he has an assignment, he often asks his siblings for help. They, however, cannot always help him. Therefore, he always has tenets that he will always be fine as long as he submits the assignment even though he does not work on it.

Meanwhile, RRW has unique behavior. She likes to wear her uniform during the online learning system. It is one of her desires to feel the offline 
approach to studying at school. Like the other informants, she studies with her books borrowed from the school. She also studies all by herself, but sometimes asks her mother for help. Unfortunately, she does not have only tools to study, she asks her mother for lending her the phone so she can submit the assignment.

During the COVID-19, HNF is accustomed to online learning. Every day, the teachers give him assignments to mark the classroom has already conducted. In his family, the availability of technology becomes a large problem. The family only has two smartphones owned by parents. HNF has to share and ask his mother for studying. He also states that it is difficult to attend online classes due to connectivity. It also leverages his quality of studying because of the absenteeism of the teacher. Furthermore, her mother does not fully understand the use of technology. She utterly uses it for communication.

Practical learning is also relegated due to the sudden change. JEF has to study at home and does not meet her friends. As same as the other informants, the presence of her teachers constantly decreases where they do not explain the materials. Instead, JEF receives the assignments every day on Telegram and WhatsApp. While using technology, she has a historical smartphone that she got from winning a competition. She won the cash prize and used the money and half of her father's saving to buy the phone. She is aware of her condition knowing that it is not easy to have digital devices. Not only does she save up her money to buy the phone, but she also saves up for the internet. She states that the intensity of the online-learning system has led her to use the internet more often. Her father also spends his saving to provide the internet for his children so they can still attend the classroom and be punctual.

\section{c. Survival of the Fittest in the Rural and Urban Areas}

The low-income society is extremely prone to the effects caused by COVID-19. Not only does it affect their financial stability, but also the education liability. The social facets of the informants construct the understanding of their strategies to keep up with the inequitable home-learning system. The unprecedented circumstance has forced them to be involved in their shortage of access and adapt to the enforcement.

Most of them encounter many challenges while doing online learning. The background of socioeconomic status is on the rise of becoming a crucial problem 
that also leads to the devastating reality. The educational attainment of their parents also becomes the cultural capital and measurement of success for the poor students. In following the home-learning system, parents are expected to accompany and assist their children at home. If the students have well-educated parents, it will be relatively easier to study and adapt to the system.

However, poor counterparts do not have the capital. For instance, ADR, ANG, DAF, and FEB were not born from well-educated parents. They only graduated from elementary or even junior high school. The students cannot ask for help to study at home. Besides, JEF, DAF, and FEB have to go to their friends to help them finish the assignment. FEB needs to courageously ask his neighbor for help because both of his parents do not understand the materials. DAF has to study all by himself because he only lives with his grandmother. His parents already divorced while her mother has moved out of town to work as a housemaid. It asserts that DAF cannot expect to have supporting roles in his study.

As stated above, it is acknowledged that their parents are busy working so they cannot take their time to accompany their children studying. If they force themselves to spare their working time, they will lose the opportunity of working which leads to the inability to earn money. On the other side, they do not fully comprehend the materials.

The background of a family is not solely a measurement of success, but it is more likely to be the availability of learning resources. All of the interviewees state that the worksheets consists of materials, summaries, and assignments. According to the research by Aggraini, et. al. (2006), the worksheets can increase the activeness of students while minimizing the role of the teacher. It is not the main resource because it just represents a glimpse of materials in the studying process. It is made to simplify the understanding of students. However, it should necessarily be addressed to complement other resources. Although, the function of LKS is shifted to be the indicator of evaluating the process (Shobirin, et. al., 2013). This condition is surely sickening if there are no other resources or supporting roles for students.

When people are away from during school hours, the worksheets become the primary resource. However, all of the informants claimed that it is not understandable compared to other resources rounded up by oral explanation. The 
most difficult subjects for them are mathematics and Javanese. Mathematics can be quite complicated when they have to absorb the materials by knowing and fathoming every step of sub materials. Meanwhile, Javanese is considered to be difficult because they do not speak Javanese daily.

The other strategy to participate in the home-learning system is watching educational programs on television. It is mainly provided by the channel of TVRI every morning. For the students who have a television at home, it is helpful to do mathematics afterward. Nevertheless, two informants do not have television, namely ADR and ANG. Both of them have to go to their neighbor's house for 30 minutes to join watching the program. Luckily, the neighbor welcomes them very well to study and watch television together. Unfortunately, the television program is not effective in increasing their understanding related to certain subjects. The visual medium is sometimes too quick to some extent and there is no recording.

Followed by another problem, the uneven access of technology to conduct online learning, transfer materials, and submit the assignments strongly exists. Some of the informants stated that the teachers get them to be punctual for submission. They ought to use digital devices to complete the courses. For the students who have the resources (whether it belongs to them or their parents), it is not a big deal. Meanwhile, the condition dramatically challenged ANG, DAF, and FEB to adapt to the system. The teachers of ADR come up with a solution where the students can put their assignments over the store near their houses. On the contrary, ANG does not often submit the assignments. DAF and FEB also claimed that they are often late to complete all of them.

The strategies undertaken by these informants in four regencies are, however, seemingly different. The living areas have demanded them to apply in varying degrees. First, BIP, HNF, JEF, and RRW are the students living in the urban area. They get to use the digital devices to either submit or receive the assignments. Even though the parental participation does not significantly get involved during their studies, they can still navigate their action steps to follow the home-learning system. Meanwhile, the other informants namely DAF, FEB, $\mathrm{ADR}$, and ANG live in the rural area. Nestled in the low-income families, they encounter more roadblocks rather than those who live in the urban. They have to rely on their neighborhood and school supplies (books, worksheets, etc.) to 
succeed the learning process. However, they are obviously left behind due to a lack of access in technology. Some of them have to ask their neighbors to access their learning system, some of them only get to watch televisions to receive the information regarding the material subjects. In other words, students living in the urban are typically more resourced than those in the rural area. It exposes the social inequality in education where they struggle to wade the constraint.

This condition dramatically disrupted the life cycle, as the pandemic has a huge increase in demand of supplemental learning resources. For the poor students, they afford themselves to seek out online learning resources either prompted by the schools or of their own accord (Bacher-Hicks, et. al., 2020). It clearly shows that the digital divide in education, especially in education, widens the socioeconomic gaps. For the schools in rural area, this situation has challenged the education system and forced educators to shift to an online mode of teaching overnight. Many academic institutions that were earlier reluctant to change their traditional pedagogical approach had no option but to shift entirely to online teaching-learning (Dhawan, 2020).

In fact, digital transformation is not a novel issue. It has been accompanying the education field for some years that several stakeholders of education must feel concerned. Still, solutions are highly needed due to the phenomenon above. The regional analysis must be showed up to provide the better learning process. Zhang, et. al. (2015) claimed that three top cities in the United States put their interest to the mobile education. The school districts in Chicago, New York, and Los Angeles were also the pioneers in adopting iPads. It is likely due to the equal access of technology. The schools in urban area are more resourced either by the stakeholders or local government. Hence, equal support should necessarily be given to the schools in rural area in order to optimize the learning process.

The digital divide, however, is a concept frequently used for addressing this issue. The term refers to the condition where the social gap happens to uneven access of technology to any classes in the society. It also remains in a public policy debate where it also affects the social, politics, and economic factors (Srinua \& Bohlin, 2011). In addition, it worsens the social inequality in education. In a research conducted by Hadiyat (2014), as if the technology is equally distributed and utilized as the primary means in the learning process, it will 
increase the optimization of the process itself. However, the reality does not always go as the plan. The emergence of online learning during the time of COVID-19 increasingly appears the roadblocks for the lower class in structure. Waller, et. al. (2020) further suggested that as people in relatively privileged positions and with access to a potential audience, they also have a duty to highlight the social and economic inequalities this crisis has exacerbated, whether it is amongst the economically disadvantaged, the old and/or other underprivileged communities.

As have been previously stated above, sociological approaches exacerbate the issue that the COVID-19 widens the education gap between the rich and poor students. Those who have economic, cultural, social, and symbolic capital will surely make education more accessible and perpetual. Nonetheless, for those who do not have access, this is yet another challenge that they have to work hard to overcome. The lower classes will continue to navigate their way around the limits of their daily lives to have better access to the things they need to survive. The capital of poor students is not equitable compared to the rich ones (Martono, et. al., 2019). Only those who have the resources to buy gadgets and to get an internet connection in their homes are the ones who are privileged to continue their learning despite the physical distance.

We describe the results of the informants that the students have those four forms of capital afterward. Again, the amount of capital remains different. The schooling system simultaneously navigates the capital of rich students while the poor are neglected. The system has an assumption that the capital leads them to get good grades at school. The academic achievement gap has bedeviled educators for years.

Back to the normal learning system at school, the educators had the same opportunity to access the education, provided by the presence of teachers and supporting facilities. Contrary to the findings of the existing statement, it still shows different results; family socio-economic status still has a greater impact on children's educational opportunities and achievements. It provides clear implications that rich students are more capable of cultivating good grades than the poor (Li \& Qiu, 2018; Plagens, 2011; Thomson, 2018). However, there are still issues that need attention from future research. First, with cross-sectional 
data, the result cannot fully capture the causality of certain paths, such as the impact of socioeconomic status on children's academic achievement. There can be learning resources, additional courses, and other facilities. Educational opportunities and parental participation are more likely to be factors that determine school performance.

While the schools are shifted to conduct online learning, it will no longer accommodate the students to utilize the prior physical facilities. The nuance of the online learning system constructs the concept of individualism, where the capital is the main tool to increase their school performance. The individualism has forced the poor students to somehow lose due to the financial constraints. The schools assumed that they have reliable access to follow the system while the reality is upended. The schools (read: teachers) elaborate that with the idea of intense parental participation. They consider the parents able to help their children in the system, ranging from understanding the materials to submitting the assignments. Moreover, schools overlook the condition of having digital devices. It strains them to be more struggling to participate remotely in the classroom.

In the sociological aspect, the students come from various family backgrounds. It can be shown from the educational attainment of their parents which also leverages the support given to their children. Mekonnen (2017) and Effong \& Igiri (2015) also investigated that the educational background of their family has a significant impact to stimulate the intellectuality among their children. Besides, the qualifications of education attainment among parents indicate their support to be more systematic and punctual. Well-educated parents are more likely to be helpful in school performance (Grace, et. al., 2012; Nyarko, 2011; Oginni, 2018).

Therefore, this research predominantly focuses on the problem faced by students from low-income and low-educated families. They struggle to make it work by asking for help. Their parents are also lack of competence to comprehend and teach the materials. The financial circumstance has also suffocated them to have a proper living.

If the mechanism is continuously neglected, the students will fizzle out during the process. The poor students have to struggle in adapting the intellectual capability of their rich counterparts whilst learning at home. As the agent of social 
reproduction, education is being incriminated to thwart the meritocracy: the poor students will remain poor in the future.

There might be several concerns regarding the implementation of the home-learning system. First, the role of the teacher is entailed to accommodate and look after the diverse background of students. The background includes economic, social, and cultural aspects. This concern should be the fundamental factor for carrying out the system. Second, the teachers should complement the learning's necessities by giving the handout to every subject so it can reduce the burden among students. Third, delegating group tasks might be an alternative solution due to the lack of parental participation during school hours. The group mitigates the drawbacks to understand the materials, do the assignments, and store the sources by using digital devices. Not only does the device facilitate learning, but it also simplifies the virtual connection between teachers and students.

\section{CONCLUSION}

This allows the conclusion these are the problems and the strategies afterward, such as the difficulty of understanding the materials due to the absenteeism of teachers. The educational background of parents might be the main cause. The results show that low-educated families cannot fully participate in the learning process. It is because they only have low comprehension of the materials. The strategy undertaken by poor students is to ask their neighbors or classmates for help. When nobody is present to help them at the moment, they have to utilize the worksheets as their main resources. Also, various television shows might be beneficial for them to gain some useful information. However, only some of them have television while others have to watch together with their neighbors. Second, having digital devices is also becoming another problem for poor students. The home-learning system is fixated on receiving and transferring the assignments on the phone. For those who have the devices, it is surely not a huge challenge. Contrary to the situation shows that the students who do not have the devices need to struggle to make it work. Another strategy to tackle this issue afterwards is to submit the assignments in an offline format. The shortage of online learning resources has caused them to be unable to receive complete information, which leads them to only utilize the worksheets. 


\section{REFERENCES}

Acar, E. 2011. "Effects of social capital on academic success: A narrative synthesis." Educational Research and Reviews 6(6):456-461. https://doi.org/10.5897/ERR.9000134

Anggraini, R., S. Wahyuni, \& A. D. Lesmono. 2016. "Pengembangan Lembar Kerja Siswa (LKS) Berbasis Keterampilan Proses di SMAN 4 Jember." Jurnal Pembelajaran Fisika 4(4):350-356. https://jurnal.unej.ac.id/index.php/JPF/article/view/3089

Arkorful, V. \& N. Arbaidoo. 2014. "The role of e-learning, the advantages and disadvantages of its adoption in Higher Education." International Journal of Education and Research 2(12):397-410. http://ijern.com/journal/2014/December-2014/34.pdf

Asendy, S., G. A. Sukoco, \& R. E. Purba. 2020. "Riset dampak COVID-19: potret gap akses online 'Belajar dari Rumah' dari 4 provinsi.” Retrieved May 6, 2020 (https://theconversation.com/riset-dampak-covid-19-potret-gapakses-online-belajar-dari-rumah-dari-4-provinsi-136534)

Bacher-Hicks, A., Goodman, J., Mulhern, C. "Inequality in Household Adaptation to Schooling Shocks: Covid-Induced Online Learning Engagement in Real Time." National Bureau of Economic Research Working Paper Series 7(27555):1-28. DOI: $10.3386 / w 27555$

Desan, M. H. 2013. "Bourdieu, Marx, and Capital: A Critique of the Extension Model." Sociological Theory 31(4):318-342. https://doi.org/10.1177/0735275113513265

Dhawan, S. 2020. "Online Learning: A Panacea in the Time of COVID-19 Crisis." Journal of Educational Technology 1-18. DOI: 10.1177/0047239520934018.

Dhull, I. \& M. S. Sakshi. 2017. “Online Learning.” Research Paper 3(8):32-34. https://issuu.com/thewriterspublication/docs/12-sakshi

Grace, A. M., O. O. Jethro \& J. F. F. Aina. 2012. "Roles of Parent on The Academic Performance of Pupils in Elementary Schools." International Journal of Academic Research in Business and Social Sciences 2(1):196$201 . \quad$ http://www.documenter.com/get/DVwrtUqfMYD2jlDodkf5cSCjY9IdxnIZaW4JHaY1fXY,/R OLES-OF-PARENT-ON-THE-ACADEMIC-PERFORMANCE.pdf

Hadiyat, Y. D. 2014. "Digital Divide in Indonesia (Case Study in WakatobiRegency)". Jurnal Pekommas 17(2):81-90. http://jurnal.kominfo.go.id/index.php/pekommas/article/download/192/180 
Häuberer, J. 2011. "The Founding Concepts of Social Capital - Bourdieu's Theory of Capital and Coleman's Rational-Choice Approach to Social Capital." Pp. 35-51 in: Social Capital Theory. VS Verlag für Sozialwissenschaften.

Huag, X. 2019. "Understanding Bourdieu - Cultural Capital and Habitus." Review of European Studies 11(3):45-49. DOI:10.5539/res.v11n3p45

Li, Z. \& Qiu, Z. 2018. "How does family background affect children's educational achievement? Evidence from Contemporary China." Journal of Chinese Sociology 5(13). https://doi.org/10.1186/s40711-018-0083-8

Martono, N. (2020) "Pendidikan Borjuasi di Masa Pandemi." Media Indonesia. Retrieved May 4, 2020 (https://m.mediaindonesia.com/read/detail/309931pendidikan-borjuasi-di-masa-pandemi).

Martono, N., S. Dadan, E. Puspitasari, \& Mintarti. 2019. Kontestasi Habitus di Sekolah Publik. Depok: RajaGrafindo Persada.

Mekonnen, M. A. 2017. "Effects of Family Educational Background, Dwelling and Parenting Style on Students' Academic Achievement." Educational Research and Reviews 12(18):939-949. doi: 10.5897/ERR2017.3276

Nguyen, T. 2015. "The Effectiveness of Online Learning: Beyond No Significant Difference and Future Horizons." Journal of Online Learning and Teaching. 11(2):309-319. http://jolt.merlot.org/Vol11no2/Nguyen_0615.pdf

Oginni O. I. 2018. "Home Background and Students Achievement in Mathematics." Journal of Sociology and Anthropology 2(1):14-20. DOI: $10.12691 /$ jsa-2-1-3

Plagens, G. K. 2011. "Social Capital and Education: Implications for Student and School Performance." Education and Culture 27(1):40-64. https://doi.org/10.1353/eac.2011.0007

Saavedra, J. 2020. "Educational challenges and opportunities of the Coronavirus (COVID-19) pandemic." Education for Global Development. Retrieved May, 72020 (https://blogs.worldbank.org/education/educationalchallenges-and-opportunities-covid-19-pandemic).

Shobirin, M., Subyantoro, \& A. Rusilowati. 2013. "Pengembangan Lembar Kerja Siswa Bahasa Inggris Bermuatan Nilai Pendidikan Karakter Kelas V Madrasah Ibtidaiyah Semarang." Journal of Primary Education. 2(2):6370. DOI 10.15294/JPE.V2I2.3065 
Slameto. 2020. "5 Fakta Pendidikan di Tengah Wabah Corona." Detiknews. Retrieved May 7, 2020 (https://news.detik.com/kolom/d-4969335/5-faktapendidikan-di-tengah-wabah-corona).

Srinuan, C., Bohlin, E. 2011. "Understanding the digital divide: A literature survey and ways forward". Pp. 1-39 in Innovative ICT Applications Emerging Regulatory, Economic and Policy Issues. https://www.econstor.eu/bitstream/10419/52191/1/672623358.pdf

Nyarko, K. 2011. "Parental School Involvement: The case of Ghana." Journal of Emerging Trends in Education Research and Policy Studies 2(5):378-381. http://jeteraps.scholarlinkresearch.com/articles/Parental\%20School\%20Inv olvement.pdf

Thomson, S. 2018. "Achievement at School and Socioeconomic Background: an Educational Perspective" Science Learning 3(5). https://doi.org/10.1038/s41539-018-0022-0

Waller. R., Hodge, S. , Holford, J., Milana, M., Webb, S. 2020. "Lifelong education, social inequality and the COVID-19 health pandemic." International Journal of Lifelong Education 39(3):243-246. DOI: 10.1080/02601370.2020.1790267

Zhang, M., Trussell, R., P.., Tillman, D., A., An, S., A. 2015. "Tracking the Rise of Web Information Needs for Mobile Education and an Emerging Trend of Digital Divide" Computers in the Schools: Interdisciplinary Journal of Practice, Theory, and Applied Research 32(2):83-104. DOI: 10.1080/07380569.2015.1030531. 